\title{
Assessment of Integrated Nutrient Management on Soil Properties and Yield Attribute of Chickpea (Cicer arietinum L.) Var. Samrat
}

\author{
Lokender Singh", Arun Alfred David, Narendra Swaroop and Tarence Thomas \\ Department of Soil Science and Agricultural Chemistry, Naini Agricultural Institute, \\ Sam Higginbottom University of Agriculture, Technology and Sciences, \\ Prayagraj- 211 007, U.P. India \\ *Corresponding author
}

\section{A B S T R A C T}

\section{Keywords \\ Chickpea, Seed Rhizobium, FYM, Nitrogen, Phosphorus, and Potassium, Soil Health, Bio fertilizer, Manure etc}

Article Info

Accepted: 26 July 2020 Available Online: 10 August 2020

\begin{abstract}
An experiment entitled "Assessment of Integrated Nutrient Management on Soil Properties and Yield Attribute of Chickpea (Cicer arietinum L.)Var.-samrat" was conducted at central research farm, department of Soil Science and Agricultural Chemistry, Naini Agricultural Institute, Sam higginbottom University of Agriculture, Technology and Sciences, Prayagraj which is located at $25^{\circ} 58^{\prime}$ 'North latitude and $81^{\circ} 52^{\prime}$ East longitude with an altitude of 98 meter above mean sea level and is situated $5 \mathrm{~km}$ away on the right, bank of yamuna river. The soil of the experimental field was sandy loam in texture. Randomized block design fallowed here with 9 treatment combinations replicated 3 times. Recommended dose of fertilizers i.e. Nitrogen, Phosphorus and Potassium, was applied @ 20:60:40 kg ha ${ }^{-1}$ as Di Ammonium phosphate $\left(46 \% \mathrm{P}_{2} \mathrm{O}_{5}, 18 \% \mathrm{~N}\right)$, Di Ammonium phosphate $\left(46 \% \mathrm{P}_{2} \mathrm{O}_{5}, 18 \% \mathrm{~N}\right)$, Muriate of Potash $\left(60 \% \mathrm{~K}_{2} \mathrm{O}\right)$, (Rhizobium $20 \mathrm{~g} \mathrm{~kg}^{-1}$ seed), FYM $6 \mathrm{t}$ $\mathrm{ha}^{-1}$. The trial consist of nine treatments viz., $\mathrm{T}_{1}-(\mathrm{Control}), \mathrm{T}_{2}-\left(\mathrm{N}_{2}+\mathrm{F}_{2}\right)\left(@ 50 \% \mathrm{RDF}+3 \mathrm{t} \mathrm{ha}^{-1}\right.$ FYM $), \mathrm{T}_{3}-\left(\mathrm{N}_{1}+\mathrm{F}_{2}\right)\left(@ 100 \% \mathrm{RDF}+3 \mathrm{tha}^{-1} \mathrm{FYM}\right), \mathrm{T}_{4}-\left(\mathrm{N}_{2}+\mathrm{F}_{1}\right)\left(\right.$ @ 50\% RDF + $\left.6 \mathrm{t} \mathrm{ha}^{-1} \mathrm{FYM}\right)$, $\mathrm{T}_{5}-\left(\mathrm{N}_{1}+\mathrm{F}_{1}\right)\left(@ 100 \% \mathrm{RDF}+6 \mathrm{t} \mathrm{ha}^{-1} \mathrm{FYM}\right), \mathrm{T}_{6}-\left(\mathrm{N}_{2}+\mathrm{R}_{2}\right)\left(@ 50 \% \mathrm{RDF}+10 \mathrm{~g} \mathrm{~kg}^{-1} \mathrm{seed}\right.$ Rhizobium), $\mathrm{T}_{7}-\left(\mathrm{N}_{1}+\mathrm{R}_{2}\right.$ ) (@100\% RDF $+10 \mathrm{~g} \mathrm{~kg}^{-1}$ seed Rhizobium), $\mathrm{T}_{8}-\left(\mathrm{N}_{2}+\mathrm{R}_{1}\right.$ ) (@ $50 \% \mathrm{RDF}+$ $20 \mathrm{~g} \mathrm{~kg}^{-1}$ seed Rhizobium), $\mathrm{T}_{9}-\left(\mathrm{N}_{1}+\mathrm{R}_{1}\right)\left(\right.$ @ $100 \% \mathrm{RDF}+20 \mathrm{~g} \mathrm{~kg}^{-1}$ seed Rhizobium $)$. The result of a present investigation revealed that the application of low soil $\mathrm{pH}(6.88)$ by $\mathrm{T}_{9}-\left(\mathrm{N}_{1}+\mathrm{R}_{1}\right)$ (@100\% $\mathrm{RDF}+20 \mathrm{~g} \mathrm{~kg}^{-1}$ seed Rhizobium), electrical conductivity $\left(0.15 \mathrm{dS} \mathrm{m}^{-1}\right)$ by $\mathrm{T}_{1}-$ Control, particle density $\left(2.21 \mathrm{mg}^{-3}\right.$ ) by $\mathrm{T}_{8}-\left(\mathrm{N}_{2}+\mathrm{R}_{1}\right)$ (@ $50 \% \mathrm{RDF}+20 \mathrm{~g} \mathrm{~kg}^{-1}$ seed Rhizobium), and bulk density $\left(1.06 \mathrm{mg}^{-3}\right)$ by $\mathrm{T}_{9}-\left(\mathrm{N}_{1}+\mathrm{R}_{1}\right)$ (@ $100 \% \mathrm{RDF}+20 \mathrm{~g} \mathrm{~kg}^{-1}$ seed Rhizobium), the higher organic carbon, available nitrogen, available phosphorus, available potassium, of 0.49:357.65:38.19:228.41 kg ha-1 was labelled in treatment $\mathrm{T}_{9}-\left(\mathrm{N}_{1}+\mathrm{R}_{1}\right)$ (@ $100 \% \mathrm{RDF}+20 \mathrm{~g} \mathrm{~kg}^{-1}$ seed Rhizobium) comparison to control. The combined application of Rhizobium and FYM along with control, has led to improvement in soil health potential, nutrient availability and yield sustenance under Chick pea crop cultivation in which found that the treatment $\left(\mathrm{T}_{9}\right)$ consisting of (@100\% RDF + 20 $\mathrm{g} \mathrm{kg}^{-1} \mathrm{seed}$ Rhizobium) give best result among other treatments.
\end{abstract}

\section{Introduction}

Pulses are important source of dietary protein and have unique ability of maintaining and restoring soil fertility through biological nitrogen fixation as well as addition of ample amount of residues to the soil. Pulse crops leave behind reasonable quantity of nitrogen in soil to the extent of $30 \mathrm{~kg} \mathrm{ha}^{-1}$. In India pulses are grows nearly in 25.43 million 
hectare with an annual production of 19.78 million tonnes and an average productivity of $679 \mathrm{~kg} \mathrm{ha}^{-1}$ (Anonymous, 2013).

In 2017-18, chickpea was cultivated in about 106 Lakh hectare. The country harvested a record production of $>111$ Lakh ton at the ever highest productivity level of $1056 \mathrm{~kg}$ ha 1 . As usual, MP has contributed a significant $34 \%$ of the total gram area and $41 \%$ of total gram production in the country, thereby ranking first both in area and production. Maharashtra (18\%) and Rajasthan (13\%) were the next in terms of area. More than 90 per cent of gram production of the country during the period under report has been realized by 10 states of MP, MS, Rajasthan, Karnataka, UP, AP, Gujarat, Jharkhand, CG and Telangana. Chickpea is the world's third most important food legume with $96 \%$ cultivation in the developing countries. Uttar Pradesh is the fifth rank in chickpea production. The study was conducted in the state of Uttar Pradesh (UP). The economy of U.P. is predominately agrarian. In this region there are sixteen districts, out of which Kanpur Dehat and Unnao were randomly selected for the present study. Uttar Pradesh state has a total area of 577 thousand ha, production of 475.4 thousand tones and yield $824 \mathrm{~kg} \mathrm{ha}^{-1}$ under chickpea cultivation.

Chickpeas are a nutrient-dense food, providing rich content $20 \%$ or higher of the daily value (DV) of protein, dietary, fiber, folate and certain dietary minerals, such as iron and phosphorus in a 100 gram reference amount. Thiamin, vitamin, $\mathrm{B}_{6}$, magnesium and zinc contents are moderate, providing 10 $16 \%$ of the DV. Compared to reference levels established by the United Nation Food and Agriculture Organization and World Health Organization, proteins in cooked and germinated chickpeas are rich in essential amino acids such as lysine, isoleucine, tryptophan, and total aromatic amino acids.
A 100 -gram ( $3 \frac{1}{2}$-ounce) reference serving of cooked chickpeas provides 686 kilojoules (164 kilocalories) of food energy. Cooked chickpeas are $60 \%$ water, $27 \%$ carbohydrates, $9 \%$ protein and $3 \%$ fat. $75 \%$ of the fat content is unsaturated fatty acids for which linoleic acid comprises $43 \%$ of the total fat. (Pulses Revolution - From Food to Nutritional Security).

Synchronizes the nutrient demand of the crop with nutrient supply from native and applied sources. Provides balanced nutrition to crops and minimizes the antagonistic effects resulting from hidden deficiencies and nutrient imbalance. Improves and sustains the physical, chemical and biological functioning of soil.

Organic manures viz., FYM, Vermicompost (VC), poultry manure (PM) and oilcakes help in the improvement of soil structure, aeration and water holding capacity of soil. Further, it stimulates the activity of microorganisms that makes the plant to get the macro and micronutrients through enhanced biological processes, increase nutrient solubility, alter soil salinity, solidity and $\mathrm{pH}$ (Alabadan et al., 2009). Organic compost is a very important method of providing the plants with their nutritional requirements without having an undesirable impact on the environment (Haruna et al., 2011).

Rhizobium inoculation increased the root nodulation through better root development and more nutrient availability, resulting in vigorous plant growth and dry matter production which resulted in better flowering, fruiting and pod formation and ultimately there was beneficial effect on seed yield (Sardana et al,. 2006). A judicious use of organic manures and biofertilizers may be effective not only sustaining crop productivity and in soil health, but also in supplementing chemical fertilizers of crop (Jaipal et al., 
2011). Among the various fertilizers, biofertilizers are important sources of nutrients. Biofertilizers are natural fertilizers containing micro-organism which help in enhancing the productivity by Biological nitrogen fixation or solubilization of insoluble phosphate or producing hormones, vitamins and other growth regulators required for plant growth (Bhattacharya, 2000).

Nitrogen also plays an important role in synthesis of chlorophyll and amino acid, which contributes to the building units of protein and thus the growth of plants. Insufficient nitrogen may reduce yield drastically and deteriorates the quality of produce.

Cluster bean being a legume crop which has the capacity to fix atmospheric nitrogen by its effective root nodules the major part of nitrogen is met through Rhizobium present in the root nodules hence, crop does not require additional nitrogen for its initial growth and development stage. The nitrogen application increased crude protein, crude fiber contents, ash percentage, carbohydrates, and leaf area per plant, dry matter and green fodder yield of cluster bean cultivars (Bakar et al., 2010)

Organic manures is very good media for microorganisms growth and development also maintain the soil fertility status. It is that combination of organics and mineral fertilizers highly enhance the productivity of soil. Frequent use of inorganic fertilizer causes reduction in the crop yields and resulted in imbalance of nutrients in the soil, which has adverse effect on soil health. Combined use organic manures and alone application improve the soil physical, chemical and biological properties and proper utilization of applied fertilizers for improving seed yield and quality of crop (Patil et al., 2012).
Phosphorus is critical to chickpea yield because it is reported to stimulate growth, initiate nodule formation as well as influence the efficiency of the rhizobium-legume symbiosis (Haruna and Aliyu, 2011).

The potassium is the third most important essential nutrient after nitrogen and phosphorus. The potassium activates more than 60 enzymes and enzymatically catalyzes the system involved in photosynthesis, metabolism and translocation of carbohydrates and proteins, membrane permeability, stomatal regulation and water utilization. Other benefits ascribed to $\mathrm{K}$ include resistance of plants against pests, disease and stresses caused by drought, frost, salinity, solidity and in assuring improved crop quality characteristics (Kherawat et al., 2013).

\section{Materials and Methods}

The investigation was conducted on Assessment of Integrated Nutrient Management on Soil Properties and Yield Attribute of Chickpea (Cicer arietinum L.) Var. Samrat comprise of a field experiment which was carried out at the Soil Science Central Research Farm, Sam Higginbottom University of Agriculture, Technology and Sciences, Prayagraj during kharif season 2019-20. The details about the experiment site, soil and climate is described in this chapter together with the experimental design, layout plan, culture practice, particulars of treatments, planting material and techniques employed for the parameters. Itis located at $25^{\circ} 58^{\prime}$ North latitude and $81^{\circ} 52^{\prime}$ East longitude with an altitude of 98 meter above mean sea level. The area of Prayagraj district comes under subtropical belt in the South east of UttarPradesh, which experience extremely hot summer and fairly cold winter. The maximum temperature of the location reaches up to $46^{\circ} \mathrm{C}-48^{0} \mathrm{C}$ and seldom falls as low as 
$4^{0} \mathrm{C}-5^{0} \mathrm{C}$. The relative humidity ranged between 20 to 94 percent. The average rainfall in this area is around $1100 \mathrm{~mm}$ annually.

The treatment consisted of nine combination of inorganic source of fertilizers $\mathrm{T}_{1}$-(Control), $\mathrm{T}_{2}-\left(\mathrm{N}_{2}+\mathrm{F}_{2}\right)$ (@50\%RDF + $\left.3 \mathrm{t} \mathrm{ha}^{-1} \mathrm{FYM}\right)$, $\mathrm{T}_{3}-\left(\mathrm{N}_{1}+\mathrm{F}_{2}\right)\left(@ 100 \% \mathrm{RDF}+3 \mathrm{t} \mathrm{ha}^{-1} \mathrm{FYM}\right)$, $\mathrm{T}_{4}-\left(\mathrm{N}_{2}+\mathrm{F}_{1}\right)\left(@ 50 \% \mathrm{RDF}+6 \mathrm{t} \mathrm{ha}^{-1} \mathrm{FYM}\right)$, $\mathrm{T}_{5}-\left(\mathrm{N}_{1}+\mathrm{F}_{1}\right)\left(@ 100 \% \mathrm{RDF}+6 \mathrm{t} \mathrm{ha}^{-1} \mathrm{FYM}\right)$, $\mathrm{T}_{6}-\left(\mathrm{N}_{2}+\mathrm{R}_{2}\right)$ (@50\%RDF + 10g kg-1 seed Rhizobium), $\mathrm{T}_{7}-\left(\mathrm{N}_{1}+\mathrm{R}_{2}\right)$ (@100\%RDF $+10 \mathrm{~g} \mathrm{~kg}^{-1}$ seed Rhizobium), $\mathrm{T}_{8}-\left(\mathrm{N}_{2}+\mathrm{R}_{1}\right)$ (@ $50 \% \mathrm{RDF}+20 \mathrm{~g} \mathrm{~kg}^{-1}$ seed Rhizobium), $\mathrm{T}_{9}-$ $\left(\mathrm{N}_{1}+\mathrm{R}_{1}\right)$ (@100\%RDF + 20g kg-1 seed Rhizobium). The trial was laid out in a randomized block design with three replication; plot size was 2 × $2 \mathrm{~m}$ for crop seed rate $75-100 \mathrm{~kg} \mathrm{ha}^{-1}$ (cicer arietinum L.) Var.-samrat. Samrat GNG-469 is a variety of Chickpea, having a source of RAU, Sriganganagar that were released/notified in the year 1997, into the area of adoption zone in the state of Punjab, Haryana, Delhi, North Rajasthan and west Uttar Pradesh which is having yield area $20-22\left(\mathrm{Q} / \mathrm{ha}^{-1}\right)$ with $145-150$ days of time period for maturity that have resistant of Ascochyta blight. Tolerance to wilt and root rot. Suitable for rainfed and irrigated areas (dpd.gov.in/VARIETIES). The source of Nitrogen, Phosphorus, Potassium, FYM, seed Rhizobium were DAP, MOP, Rhizobium, FYM respectively. Basal dose of fertilizer was applied in respective plots according to treatment allocation unfurrows opened by about $5 \mathrm{~cm}$. All the agronomic practices were carried out uniformly to raise the crop. Soil samples were collected from the soil $0-15 \mathrm{~cm}$ depth and kept in an oven at $1050 \mathrm{C}$ for $48 \mathrm{hrs}$. for drying, then pass through $2 \mathrm{~mm}$ sieve after that soils were analysis by using standard procedures as described for $\mathrm{pH}$ 1:2 (mlv) (Jackson 1958), electrical conductivity $\left(\mathrm{dS} \mathrm{m}^{-1}\right)$ (Wilcox 1950), organic carbon \% (Walkley and Black, 1947), available nitrogen $\mathrm{kg} \mathrm{ha}^{-1}$ (Subbiah and
Asija 1956), phosphorus $\mathrm{kg} \mathrm{ha}^{-1}$ (Olsen et al., 1954) and potassium $\mathrm{kg} \mathrm{ha}^{-1}$ (Toth and Prince 1949). The physico-Chemical properties at the start of experiment are presented in table 1 and 2 , respectively.

\section{Results and Discussion}

\section{Physico-chemical properties of soil after} Post harvest

The result in given table 3 indicates some of the important parameter on physical properties on Chick pea crop. Organic and inorganic fertilizers in conjunction on bulk density, particle density and pore space to be significant. The bulk density was $1.06 \mathrm{Mg} \mathrm{m}^{-}$ 3. Similar were also reported by Kumar et al., (2015). Particle density was $2.21 \mathrm{Mg} \mathrm{m}^{-3}$. Similar were also reported by Kumar et al., (2015) and pore space was 50.43\%. Similar finding observed were Tiwari and Kumar (2009). The slight decreased in bulk density pore space and particle density may be due to tillage operations and plant growth.

As depicted in table 4 indicate some of the important parameter of chemical properties of soil $\mathrm{pH}$ 1:2 (w/v), Electrical conductivity was $\left(0.24 \mathrm{dS} \mathrm{m}^{-1}\right)$. Similar results were also reported by Kumar et al., (2015). Organic carbon was $(0.46 \%)$. Similar results were also reported by Marti'nez-Romero et al., (2009). Available nitrogen was (357.65 $\mathrm{kg} \mathrm{ha}^{-1}$ ). Results were also reported by Zai et al., (2012). Phosphorus was (38.19 $\left.\mathrm{kg} \mathrm{ha}^{-1}\right)$, Potassium was $\left(228.41 \mathrm{~kg} \mathrm{ha}^{-1}\right)$ found significant. Similar results were also reported by Datt et al., (2013). There was a slight decrease in soil $\mathrm{pH}$ and increase in soil electrical conductivity $\left(\mathrm{dS} \mathrm{m}^{-1}\right)$, organic carbon (\%), available nitrogen $\left(\mathrm{kg} \mathrm{ha}{ }^{-1}\right)$, phosphorus $\left(\mathrm{kg} \mathrm{ha}^{-1}\right)$ and potassium $\left(\mathrm{kg} \mathrm{ha}^{-1}\right)$ it may be due to increase in levels of organic fertilizer and plant growth, which increase the plant residue into soil. 
Table.1 Physical properties of soil (pre-sowing)

\begin{tabular}{|l|c|c|}
\hline \multicolumn{1}{|c|}{ Particulars } & Results & Method employed \\
\hline Sand $(\%)$ & 62.71 & Bouyoucous (1927) \\
\hline Silt $(\%)$ & 23.10 & \\
\hline Clay $(\%)$ & 14.19 & \\
\hline Textural class & Sandy loam & \\
\hline Bulk density $\left(\mathrm{Mg} \mathrm{m}^{-3}\right)$ & 1.20 & Black (1965) \\
\hline Particle density $\left(\mathrm{Mg} \mathrm{m}^{-3}\right)$ & 2.28 & Black (1965) \\
\hline Pore space $(\%)$ & 47.36 & Black (1965) \\
\hline Water holding capacity (\%) & 49.32 & Black (1965) \\
\hline
\end{tabular}

Table.2 Chemical properties of soil (pre-sowing)

\begin{tabular}{|l|c|l|}
\hline \multicolumn{1}{|c|}{ Particulars } & Results & \multicolumn{1}{c|}{ Method employed } \\
\hline Soil EC $\left(\mathrm{dS} \mathrm{m}^{-1}\right)$ & 0.18 & Wilcox $(1950)$ \\
\hline Soil $\mathrm{pH}$ & 7.21 & Jackson $(1958)$ \\
\hline Organic Carbon $(\%)$ & 0.33 & Walkley and Black (1947) \\
\hline Available Nitrogen $\left(\mathrm{kg} \mathrm{ha}^{-1}\right)$ & 275.18 & Subbiah and Asija (1956) \\
\hline Available Phosphorus $\left(\mathrm{kg} \mathrm{ha}^{-1}\right)$ & 25.29 & Olsen et al.., (1954) \\
\hline Available Potassium $\left(\mathrm{kg} \mathrm{ha}^{-1}\right)$ & 190.66 & Toth and Prince $(, 1949)$ \\
\hline
\end{tabular}

Table.3 Effect of Nutrient Management, FYM and Rhizobium of soils physical after harvest of Chick pea

\begin{tabular}{|c|c|c|c|c|}
\hline Treatment Combination & $\mathrm{BD}\left(\mathrm{Mg} \mathrm{m}^{-3}\right)$ & PD $\left(\mathrm{Mg} \mathrm{m}^{-3}\right)$ & $\begin{array}{c}\text { Pore space } \\
(\%)\end{array}$ & $\begin{array}{l}\text { Water holding } \\
\text { capacity }(\%)\end{array}$ \\
\hline $\mathrm{T}_{1}$-(Control) & 1.18 & 2.24 & 50.43 & 47.72 \\
\hline $\mathrm{T}_{2}-\left(\mathrm{N}_{2}+\mathrm{F}_{2}\right)\left(@ 50 \% \mathrm{RDF}+3 \mathrm{tha}^{-1} \mathrm{FYM}\right)$ & 1.17 & 2.42 & 45.92 & 55.96 \\
\hline $\mathrm{T}_{3}-\left(\mathrm{N}_{1}+\mathrm{F}_{2}\right)\left(@ 100 \% \mathrm{RDF}+3 \mathrm{tha}^{-1} \mathrm{FYM}\right)$ & 1.16 & 2.47 & 44.49 & 55.24 \\
\hline $\mathrm{T}_{4}-\left(\mathrm{N}_{2}+\mathrm{F}_{1}\right)\left(@ 50 \% \mathrm{RDF}+6 \mathrm{tha}^{-1} \mathrm{FYM}\right)$ & 1.14 & 2.39 & 45.30 & 51.48 \\
\hline $\mathrm{T}_{5}-\left(\mathrm{N}_{1}+\mathrm{F}_{1}\right)\left(@ 100 \% \mathrm{RDF}+6 \mathrm{t} \mathrm{ha}^{-1} \mathrm{FYM}\right)$ & 1.12 & 2.28 & 46.84 & 51.02 \\
\hline $\begin{array}{l}\mathrm{T}_{6}-\left(\mathrm{N}_{2}+\mathrm{R}_{2}\right)\left(@ 50 \% \mathrm{RDF}+10 \mathrm{~g} \mathrm{~kg}^{-1} \text { seed }\right. \\
\text { Rhizobium })\end{array}$ & 1.09 & 2.36 & 43.82 & 57.18 \\
\hline $\begin{array}{l}\mathrm{T}_{7}-\left(\mathrm{N}_{1}+\mathrm{R}_{2}\right)\left(@ 100 \% \mathrm{RDF}+10 \mathrm{~g} \mathrm{~kg}^{-1} \text { seed }\right. \\
\text { Rhizobium })\end{array}$ & 1.1 & 2.33 & 44.88 & 53.39 \\
\hline $\begin{array}{l}\mathrm{T}_{8}-\left(\mathrm{N}_{2}+\mathrm{R}_{1}\right)\left(@ 50 \% \mathrm{RDF}+20 \mathrm{~g} \mathrm{~kg}^{-1} \text { seed }\right. \\
\text { Rhizobium) }\end{array}$ & 1.08 & 2.21 & 46.65 & 49.59 \\
\hline $\begin{array}{l}\mathrm{T}_{9}-\left(\mathrm{N}_{1}+\mathrm{R}_{1}\right)\left(@ 100 \% \mathrm{RDF}+20 \mathrm{~g} \mathrm{~kg}^{-1} \text { seed }\right. \\
\text { Rhizobium })\end{array}$ & 1.06 & 2.23 & 45.30 & 58.62 \\
\hline F- test & $\mathrm{S}$ & $\mathbf{S}$ & $\mathbf{S}$ & $\mathbf{S}$ \\
\hline S. Em. $( \pm)$ & 0.02 & 0.05 & 1.11 & 2.09 \\
\hline C.D. at 5\% & 0.06 & 0.14 & 2.36 & 6.26 \\
\hline
\end{tabular}


Table.4 Effect of Nutrient Management, FYM and Rhizobium of soil chemical properties after harvest Chick pea

\begin{tabular}{|c|c|c|c|c|c|c|}
\hline Treatment Combination & $\begin{array}{c}\text { pH 1:2 } \\
(w \backslash v)\end{array}$ & $\begin{array}{c}E C \\
\left(\mathbf{d S ~ m}^{-1}\right)\end{array}$ & $\begin{array}{l}\text { O.C } \\
(\%)\end{array}$ & $\begin{array}{c}\mathrm{N} \\
\left(\mathrm{kg} \mathrm{ha}^{-1}\right)\end{array}$ & $\begin{array}{c}\mathrm{P}_{2} \mathrm{O}_{5} \\
\left(\mathrm{~kg} \mathrm{ha}^{-1}\right)\end{array}$ & $\begin{array}{l}\mathrm{K}_{2} \mathrm{O} \\
\left(\mathrm{kg} \mathrm{ha}^{-1}\right)\end{array}$ \\
\hline $\mathrm{T}_{1}$-(Control) & 7.23 & 0.15 & 0.32 & 270.42 & 23.24 & 188.39 \\
\hline $\begin{array}{l}\mathrm{T}_{2}-\left(\mathrm{N}_{2}+\mathrm{F}_{2}\right)\left(@ 50 \% \mathrm{RDF}+3 \mathrm{tha}^{-1}\right. \\
\mathrm{FYM})\end{array}$ & 7.09 & 0.18 & 0.38 & 278.69 & 26.78 & 197.37 \\
\hline $\begin{array}{l}\mathrm{T}_{3}-\left(\mathrm{N}_{1}+\mathrm{F}_{2}\right)\left(@ 100 \% \mathrm{RDF}+3 \mathrm{tha}^{-1}\right. \\
\text { FYM })\end{array}$ & 6.95 & 0.20 & 0.40 & 301.47 & 27.48 & 208.37 \\
\hline $\begin{array}{l}\mathrm{T}_{4}-\left(\mathrm{N}_{2}+\mathrm{F}_{1}\right)\left(@ 50 \% \mathrm{RDF}+6 \mathrm{tha}^{-1}\right. \\
\mathrm{FYM})\end{array}$ & 7 & 0.16 & 0.33 & 317.47 & 31.7 & 212.42 \\
\hline $\begin{array}{l}\mathrm{T}_{5}-\left(\mathrm{N}_{1}+\mathrm{F}_{1}\right)\left(@ 100 \% \mathrm{RDF}+6 \mathrm{tha}^{-1}\right. \\
\mathrm{FYM})\end{array}$ & 7.17 & 0.22 & 0.42 & 346.19 & 31.71 & 204.29 \\
\hline $\begin{array}{l}\mathrm{T}_{6}-\left(\mathrm{N}_{2}+\mathrm{R}_{2}\right)\left(@ 50 \% \mathrm{RDF}+10 \mathrm{~g} \mathrm{~kg}^{-1}\right. \\
\text { seed Rhizobium })\end{array}$ & 7.11 & 0.21 & 0.35 & 290.65 & 32.2 & 215.25 \\
\hline $\begin{array}{l}\mathrm{T}_{7}-\left(\mathrm{N}_{1}+\mathrm{R}_{2}\right)\left(@ 100 \% \mathrm{RDF}+10 \mathrm{~g} \mathrm{~kg}^{-1}\right. \\
\text { seed Rhizobium })\end{array}$ & 7.1 & 0.18 & 0.42 & 347.61 & 35.92 & 222.1 \\
\hline $\begin{array}{l}\mathrm{T}_{8}-\left(\mathrm{N}_{2}+\mathrm{R}_{1}\right)\left(@ 50 \% \mathrm{RDF}+20 \mathrm{~g} \mathrm{~kg}^{-1}\right. \\
\text { seed Rhizobium) }\end{array}$ & 6.99 & 0.23 & 0.43 & 293.05 & 34.87 & 224.46 \\
\hline $\begin{array}{l}\mathrm{T}_{9}-\left(\mathrm{N}_{1}+\mathrm{R}_{1}\right)\left(@ 100 \% \mathrm{RDF}+20 \mathrm{~g} \mathrm{~kg}^{-1}\right. \\
\text { seed Rhizobium })\end{array}$ & 6.88 & 0.24 & 0.49 & 357.65 & 38.19 & 228.41 \\
\hline F-test & $\mathbf{S}$ & $\mathbf{S}$ & $\mathbf{S}$ & $\mathbf{S}$ & $\mathbf{S}$ & $\mathbf{S}$ \\
\hline S. Em. $( \pm)$ & 0.05 & 0.02 & 0.03 & 7.71 & 1.60 & 1.97 \\
\hline C. D. at $5 \%$ & 0.14 & 0.05 & 0.08 & 23.11 & 4.80 & 5.91 \\
\hline
\end{tabular}

The soil texture observed was sandy loamy. The soil colour in dry condition was light yellowish brown and wet condition was olive brown. In this experiment evaluated soil physical characters: $\mathrm{BD}, \mathrm{PD}$, Pore space, WHC, pH, EC, O.C, N, $\mathrm{P}_{2} \mathrm{O}_{5}$ and $\mathrm{K}_{2} \mathrm{O}$. Bulk Density (BD) found to be lowest in $\mathrm{T}_{9}$ $\left(1.06 \mathrm{Mg} \mathrm{m}^{-3}\right)$ and found to be highest in $\mathrm{T}_{1}$ $\left(1.18 \mathrm{Mg} \mathrm{m}^{-3}\right)$. Particle Density (PD) found to be lowest in $\mathrm{T}_{8}\left(2.21 \mathrm{Mg} \mathrm{m}^{-3}\right)$ and found to be highest in $\mathrm{T}_{3}\left(2.47 \mathrm{Mg} \mathrm{m}^{-3}\right)$. Pore space found to be highest in $\mathrm{T}_{1}(50.43 \%)$ and found to be lowest in $\mathrm{T}_{6}(43.82 \%)$. Water Holding Capacity (WHC) found to be highest in $\mathrm{T}_{9}$ $(58.62 \%)$ and found to be lowest in $\mathrm{T}_{8}(49.59$ $\%$ ). $\mathrm{pH}$ found to be lowest in $\mathrm{T}_{9}(6.88)$ and found to be highest in $T_{1}$ (7.23). Electrical Conductivity (EC) found to be highest in $\mathrm{T}_{9}$ $\left(0.24 \mathrm{dS} \mathrm{m}^{-1}\right)$ and found to be lowest in $\mathrm{T}_{1}$ $\left(0.15 \mathrm{dS} \mathrm{m}^{-1}\right)$. Organic Carbon (O.C) found to be highest in $\mathrm{T}_{9}(0.49 \%)$ and found to be lowest in $\mathrm{T}_{1}(0.32 \%)$. Nitrogen $(\mathrm{N})$ found to be highest in $T_{9}\left(357.65 \mathrm{~kg} \mathrm{ha}^{-1}\right)$ and found to be lowest in $\mathrm{T}_{1}\left(270.42 \mathrm{~kg} \mathrm{ha}^{-1}\right)$. Phosphorus $\left(\mathrm{P}_{2} \mathrm{O}_{5}\right)$ found to be highest in $\mathrm{T}_{9}\left(38.19 \mathrm{~kg} \mathrm{ha}^{-1}\right.$ and found to be lowest in $\mathrm{T}_{1}\left(23.24 \mathrm{~kg} \mathrm{ha}^{-1}\right)$. Potassium $\left(\mathrm{K}_{2} \mathrm{O}\right)$ found to be highest in $\mathrm{T}_{9}$ $\left(228.41 \mathrm{~kg} \mathrm{ha}^{-1}\right)$ and found to be lowest in $\mathrm{T}_{1}$ $\left(188.39 \mathrm{~kg} \mathrm{ha}^{-1}\right)$.

In conclusion the present investigation, it was apparent that application of Nutrient Management, FYM and Rhizobium. The combined application of Nutrient Management, FYM and Rhizobium, has led to improvement in soil health potential, nutrient availability and yield sustenance under Chickpea cultivation in which found that the 
treatment $\mathrm{T}_{9}-\left(\mathrm{N}_{1}+\mathrm{R}_{1}\right)($ @ $100 \% \mathrm{RDF}+20 \mathrm{~g}$ $\mathrm{kg}^{-1}$ seed Rhizobium) give best result among other treatments.

\section{Acknowledgements}

The authors are grateful to the Vice Chancellor, Departmental Head \& Staff of SSAC, SHUATS, Prayagraj for taking their keen interest and encouragement to carry out the research work.

\section{References}

Alabadan, B. A., Adeoye, P. A. and Folorunso, E. A. (2009) Effect of different poultry wastes on physical, chemical and biological properties of soil, Caspian Journal of Environmental Science, 7: 31-35.

Anonymous (2013) Indian Institute of Pulse Research, Kanpur -Vision 2020.

Bakar, K.A., Tarmizi, R.A., Mahyuddin, R., Elias, H., Wong, S.L., and Ayub, A.F.M., (2010) relationship between students' achievement motivation, attitude and academic performance in Malaysia. Procedia - Social and Behavioural Sciences, 2(2), 49064910.

Bhattacharya, S.K. (2000) current facets in potato research, proceed, Souvenir and Abstracts, National Seminar, Indian Potato Association, C. P. R.S., Modipuram Mcerut, Dec. 13-15. pp. 89.

Black C. A. (1965) methods of soil analysis vol.2, Am. Soc, Agron. madison, Wisconsin, U.S.A, 1965.

Bouyoucos, G. J. (1927) the hydrometer as a new method for the mechanical analysis of soil. Soil Sci. 23. 343-353

Datt N, Sharma RP, Sharma GD (2013) effect of supplementary use of farmyard manure along with chemical fertilizers on productivity and nutrient uptake by vegetable pea (Pisum sativum var. arenes) and build-up of soil fertility in Lahaul Valley. Indian J. Agric. Sci. 73:266-268.

Directorate of Pulses Development: http://dpd.gov.in/VARIETIES

Haruna, I. M., and Aliyu, L., (2011) yield and economic returns of sesame (Sesamum indicum L.) as influenced by poultry manure, nitrogen and phosphorus at Samaru, Nigerian Elixir Agriculture, 39: 4884-4887

Jackson, M. L. (1958) soil Chemical Analysis, Prentice Hall of India Private Limited, New Delhi.

Jaipal, Sharma S, Dixit A.K., and Sharma A.K., (2011) growth and yield of capsicum and garden pea as influenced by organic manures and biofertilizers, Indian Journal of Agricultural Sciences, 81(7): 637-642.

Kherawat, B. S., MunnaLal, Agarwal, M., Yadav, H.K. and Kumar, S. (2013) effect ofApplied Potassium and Manganese on Yield and Uptake of Nutrients by Cowpea [Vigna unguiculata (L.)]. Journal of Agricultural Physics 13 (1):22-26.

Kumar Sant Sharma Sunil Prajapati and Omveer Raghuvanshi (2015) effect of organic manures and Inorganic fertilizers on yield and economics of Green gram production (Vigna radiata L.), Indian Res. J. Genet. Biotech 7(1): $152-155$.

Martı'nez-Romero, E. (2009) diversity of Rhizobium - Phaseolus vulgaris symbiosis: overview and perspectives. Plant Soil 252, 11-23.

Olsen, S.R., Cole, C.V., Watnahe, F. S. and Dean L. A. (1954) estimation of available phosphorous in soil by extraction with sodium bicarbonate U.S. Dept. Agr.Cric. 939.

Patil, S. V., S. I. Halikatti, S. M. Hiremath, H. B. Babalad, M. N. Sreenivasa, N. S. 
Hebsur and G. Somanagouda (2012) effect of organics on growth and yield of chickpea (Cicer arietinum L.) in Vertisols. Karnataka Journal of Agricultural Sciences, 25(3): 326-331.

Sardana V, Sheoram P and Singh S. (2006) indian Journal of Pulses Research, 19: 216.

Subbiah, B. V. and Asija, C. L. (1956) a rapid procedure for the estimation of available nitrogen in soil, Current Sci. 25 259-260.

Tiwari, D. and Kumar, K. (2009) effect of biofertilizer and phosphorus level on growth, nodulation and yield of mung bean (In) International Conference on Grain Legumes: Quality Improvement, Value Addition and Trade held during, 14-16, February, 2009 at Indian Institute of Pulse Research, Kanpur.

Toth, S. J. and Prince, A. L. (1949) estimation of cation exchange capacity and exchangeable $\mathrm{Ca}, \mathrm{K}$ and $\mathrm{Na}$ Content of Soil by Flame photometer technique. Soil Sci. 67 439-445.

Walkley, A. (1947) critical examination of rapid method for determining organic carbon in soil, effect of variation in digestion condition and of inorganic soil constitutes. Soil Sci. 632-251

Wilcox, L.V. (1950) electrical conductivity, Amer. water works assoc. J. 42 775776.

Zai, A.K.E., A.R.M. Solaiman, A.J.M.S. Karim and J.U. Ahmed (2012) performance of some chickpea varieties to Rhizobium inoculation in respect of growth. $\mathrm{N}$ uptake, yield and seed protein content. Annals of Bangladesh Agriculture, 9(2): 121130.

\section{How to cite this article:}

Lokender Singh, Arun Alfred David, Narendra Swaroop and Tarence Thomas. 2020. Assessment of Integrated Nutrient Management on Soil Properties and Yield Attribute of Chickpea (Cicer arietinum L.) Var. Samrat. Int.J.Curr.Microbiol.App.Sci. 9(08): 3432-3439. doi: https://doi.org/10.20546/ijcmas.2020.908.397 